pronounced rises took place in Germany and most of the other belligerent countries. Even some of the neutral countries showed a distinct reaction, which in the case of Switzerland was more marked than that of England and Wales.

\section{Rehabilitation of Adult Prostitutes}

Experience shows that the problem of prostitution tends to acquire particular importance in time of war, not only for the countries directly involved but also for other countries, and the publication by the League of Nations Secretariat of a third and concluding volume of studies on this subject is therefore opportune (League of Nations Pamphlet, iv, 4, Messrs. Allen and Unwin, 40 Museum Street, London, W.C.1 ; 1939. 3s. 6d. net). An endeavour is made in this volume to elucidate the controversial question of possibilities of reclaiming prostitutes for re-entry into the normal life of the community. Institutional training is discussed at some length, and an account is given of the different approaches made by various types of institutions, religious and lay, to the problem. The Advisory Committee which studied this question came to the conclusion that, if certain principles are applied and certain psychological factors recognized, rehabilitation of adult prostitutes is, within limits, both feasible and successful. The volume should be useful not only to those directly concerned with the problem of rehabilitation, but also to all social workers who have to deal with the very complex question of prostitution in general.

\section{London School of Hygiene and Tropical Medicine}

The report for 1938-39 of the London School of Hygiene and Tropical Medicine, incorporating the Ross Institute, is, as usual, of great interest. It should be realized that studies which seem minute and insignificant, such as the survival and fertility of insects under highly unfavourable conditions, may be of the utmost importance to planters and owners of big estates. They should subscribe more generously to a School which does so much for their welfare. The Institute, while busy at home with many discoveries, including bacterial survival for well over a century, has been continuing the attack on the problems of Anopheles minimus in Assam, a mosquito which can be controlled more effectively by shading than by the use of drugs.

It is very satisfactory to learn that in the chief field stations of tea estates in India it has been possible to train a staff of Indians as surveyors of malaria and laboratory assistants. The annual malaria control course for laymen which started at the Institute in 1929 is free, and from small beginnings has now attracted more than a thousand learners. Ceylon has had in the past great outbreaks of malaria due to drought, but the failure of two monsoons during the year under survey did not lead to the major outbreak that might have been expected. The Ceylon Government and the Estates Malaria Control scheme confined the trouble to minor eruptions. This is a specimen of the remarkable work that is done.
The energies of the Institute are, indeed, far flung. They have been extended to the Gold Coast and the question of mass emigration of refugees from Central Europe to British Guiana. Dr. Chester Beatty's speech at the annual 'Mosquito Day' luncheon dwelt rightly on the comparatively meagre support given. Some of the travelling specialists are constantly employed and clearly overworked.

\section{A New Type of Wood-Burning Stove}

A NEW stove, developed by the Connecticut Forest and Park Association in co-operation with Prof. L. E. Seeley, heating expert of Yale University, burns wood with an efficiency estimated at ninety per cent. It is capable of heating two or three rooms and requires filling only once or twice a day. A report issued by Science Service, of Washington, D.C., says that the new heater holds about two and a quarter cubic feet of wood, or slightly more than $50 \mathrm{lb}$. It is estimated that it will generate about 40,000 B.T.U./hr. for an eight-hour period without attention. This amount of heat is sufficient for two or three rooms in cold weather. In mild weather the heater will easily run more than twenty-four hours without attention.

The new heater differs radically in design from the usual type of wood-burning stove. Air supply is limited as in any tight heater, but all air is not directed into one space, as is customary; instead, provision is made for pre-determined amounts of air to enter the combustion chamber, while a separate air supply is allowed to mix with the highly heated gases formed by the burning wood. The wood gases are passed through small passage-ways called combustion ports where they are burned separately from the wood. The process is a partial distillation of the wood producing charcoal and gas, and the products are burned in different spaces. The result is high efficiency with a minimum of loss in soot, creosote and ash. The Governor of Connecticut, who has expressed interest in the establishment of a permanent outlet for the firewood now being wasted in the State for lack of a market, has made possible a small-scale commercial experiment in the use of wood as fuel in State institutions.

\section{Electrical Thawing}

DURING the recent cold spell, serious inconvenience has been caused in many households by the freezing of water services. In the Electrical Review of February 2, a letter from Mr. C. W. Salt, the city electrical engineer to Carlisle, is published describing an effective and 'easily applied method of thawing frozen water services, when a public A.C. supply is available. In Carlisle, where the voltage is 230 , a double-wound single-phase transformer is used, the ratio being $230 / 12$, with a regulating resistance on the primary side and an ammeter scaled $0-250$ on the secondary side. The primary is plugged into a 15 amp. radiator socket and the secondary leads are attached to a tap or pipe inside the house and to the stopcock of a neighbouring house. The regulating resistance is adjusted until the secondary current flows through 